\title{
Bioemulsifiers are not biosurfactants and require different screening approaches
}

\author{
Chibuzo Uzoigwe ${ }^{1}$, J. Grant Burgess ${ }^{2}$, Christopher J. Ennis ${ }^{1}$ and \\ Pattanathu K. S. M. Rahman ${ }^{1 *}$ \\ ${ }^{1}$ Technology Futures Institute, School of Science and Engineering, Teesside University, Middlesbrough, UK, ${ }^{2}$ School of \\ Marine Science and Technology, Newcastle University, Newcastle Upon Tyne, UK
}

Keywords: biosurfactants, bioemulsifiers, rhamnolipids, lipoproteins, lipopeptides, sophorolipids

OPEN ACCESS

Edited by:

Weiwen Zhang

Tianjin University, China

Reviewed by:

Kamaljeet K. Sekhon Randhawa, Aalborg University Copenhagen,

Denmark

Wael Ismail,

Arabian Gulf University, Bahrain

${ }^{*}$ Correspondence:

Pattanathu K. S. M. Rahman

p.rahman@tees.ac.uk

Specialty section:

This article was submitted to Microbiotechnology, Ecotoxicology and Bioremediation, a section of the

journal Frontiers in Microbiology

Received: 05 December 2014 Accepted: 13 March 2015

Published: 07 April 2015

Citation:

Uzoigwe C, Burgess JG, Ennis CJ and Rahman PKSM (2015) Bioemulsifiers are not biosurfactants and require different screening approaches. Front. Microbiol. 6:245 doi: 10.3389/fmicb.2015.00245
The terms biosurfactant and bioemulsifier have often been used interchangeably to describe surface active biomolecules. However, it is important to note that there are marked differences between them especially based on their physico-chemical properties and physiological roles. Although bioemulsifiers and biosurfactants are both amphiphilic in nature and are produced by a wide range of microorganisms, each exhibit characteristic roles in nature. These microbial surfactants have recently received increased scientific attention due to their unique characteristics relative to chemically derived surfactants. Their unique features include; non-toxicity, biodegradability, biocompatibility, efficiency at low concentrations and their synthesis from natural substrates under mild environmental conditions.

\section{The Physiological Roles of Biosurfactants and Bioemulsifers are Based on their Physicochemical Properties}

The chemical composition of biosurfactants and bioemulsifiers is different and this may contribute to their specific roles in nature and biotechnological applications. Biosurfactants are generally low molecular weight microbial products composed of sugars, amino acids, fatty acids and functional groups such as carboxylic acids. The glycolipids (rhamnolipids, sophorolipids, trehalose lipids) consist of different sugars linked to $\beta$-hydroxy fatty acids while lipopeptides (surfactin, iturin, fengycin) consist of cycloheptapeptides with amino acids linked to fatty acids of different chain lengths. These molecules are amphiphilic in nature and this property allows them to dissolve in both polar and non-polar solvents (Perfumo et al., 2009; Satpute et al., 2010; Smyth et al., 2010a,b). Biosurfactants are known for their excellent surface activity which involves lowering the surface and interfacial tension between different phases (liquid-air, liquidliquid, and liquid-solid); possessing a low critical micelle concentration (CMC) and formation of stable emulsions. The ability to lower surface and interfacial tension is by adsorption of biosurfactant onto the different phases causing more interaction and mixing of dissimilar phases. The CMC is the minimum concentration of biosurfactant required to yield the minimum surface tension in water and form micelles. They can act as wetting, foaming and solubilizing agents in different industrial processes. In oil polluted environments (solid or liquid), biosurfactants can enhance the effective dispersion and bioavailability of hydrophobic pollutants for microbial access and degradation by the process of micelle solubilization. They have the ability to mobilize hydrophobic molecules bound on solid substrata increasing the flow rate. Biosurfactants produced in a growth associated manner (trehalose lipids) confer increased cell surface hydrophobicity on the producing organism. Cell surface hydrophobicity is essential for easy access and 
subsequent uptake of hydrophobic substrates by microbial cells (Perfumo et al., 2009; Satpute et al., 2010). These biomolecules are therefore suitable agents for different bioremediation technologies.

Bioemulsifiers are higher in molecular weight than biosurfactants as they are complex mixtures of heteropolysaccharides, lipopolysaccharides, lipoproteins and proteins (Perfumo et al., 2009; Smyth et al., 2010a; Sekhon-Randhawa, 2014). They are also known as high molecular weight biopolymers or exopolysaccharides. Similar to biosurfactants, these molecules can efficiently emulsify two immiscible liquids such as hydrocarbons or other hydrophobic substrates even at low concentrations but in contrast are less effective at surface tension reduction. Therefore, they can be said to possess only emulsifying activity and not surface activity. They are also involved in solubilization of poorly-soluble substrates, thus increasing their access and availability for biodegradation. However, in an oil polluted environment, these molecules play a specific role of binding tightly to dispersed hydrocarbons and oils preventing them from merging together. This process is known as stabilization of emulsion and has been attributed to the high number of reactive groups exposed in their structures. Bioemulsifiers are able to stabilize emulsions by increasing their kinetic stability and this property has increased their usefulness in the cosmetics, food, pharmaceutical and petroleum industries. Reports have shown that the efficient emulsifying activity of bioemulsifiers is a function of their chemical composition (Calvo et al., 2009; Monteiro et al., 2010). According to Willumsen and Karlson (1997), surface active biomolecules are categorized into surfactants and emulsifiers, while surfactants play the role of surface tension reduction, emulsifiers are involved in formation and stabilization of emulsions. However, some biomolecules possess both surfactant and emulsifying properties which contributes to their unique functions and broad industrial uses.

The combination of polysaccharide, fatty acid and protein components in bioemulsifiers confers upon them better emulsifying potential and ability to stabilize emulsions. It is also important to note that some efficient bioemulsifiers consists of only polysaccharides and proteins. Emulsan is a lipopolysaccaharide bioemulsifier with a molecular weight of $1000 \mathrm{kDa}$ produced by Acinetobacter calcoaceticus RAG-1. It is one of the most widely studied emulsifiers from bacteria. In pure form, emulsan shows emulsifying activity at low concentrations (0.01-0.001\%). It increases the bioavailability of poorly soluble substrates in aqueous environments for microbial access and degradation by coating the hydrophobic substrate to form a minicapsule. The producing bacterium can also have direct access to hydrophobic substrates but the emulsifying activity is exhibited by secreted emulsan. However, this emulsifier can efficiently emulsify mixtures of aliphatic and aromatic hydrocarbons in balanced proportions but cannot emulsify their pure forms. The emulsifying activities of emulsan are therefore attributed to its fatty acid components which act as multiple sites for binding different hydrophobic phases (Choi et al., 1996; Ron and Rosenberg, 2001).

A bioemulsifier also known as emulsan produced by Acinetobacter calcoaceticus BD4 has been reported. BD4 Emulsan consists of a polysaccharide-protein complex without a lipid moiety thereby varying from RAG-1 Emulsan. BD4 emulsan exhibited its optimum emulsification of different hydrocarbons when the two components (polysaccharides and proteins) were mixed together but had no emulsifying activity when these components existed in separate forms (Kaplan and Roseberg, 1985). Kaplan et al. (1987) also explained the mechanism of emulsifying activity by the protein-polysaccharide mixture. The protein being the hydrophobic part binds the hydrocarbons in a reversible form while the polysaccharide attaches to the protein to produce a stable oil-in-water emulsion. Lukondeh et al. (2003) also described bioemulsifiers as amphiphilic, with the polysaccharide polymer as the hydrophilic part covalently attached to the protein hydrophobic part.

Furthermore, alasan is an anionic alanine-containing bioemulsifier produced by A. radioresistens KA53. This bioemulsifier is a complex of alanine, polysaccharides and proteins with a molecular mass of $1 \mathrm{MDa}$. It exists as cell-bound and secreted proteins and can efficiently emulsify a variety of hydrocarbons including; long chains, alkanes, aromatics, poly aromatic hydrocarbons (PAHs), paraffins and crude oils. Alasan can facilitate solubilization of $\mathrm{PAH}$ by aggregating them into oligomer molecules and this mechanism increases their solubility by 20 -fold, thereby speeding up biodegradation. The protein components in the alasan molecule have been associated with its ability to emulsify various hydrocarbons unlike emulsan. This is a $45 \mathrm{kDa}$ protein with highly hydrophobic regions folded over in loops contributing to emulsification and solubilization activity of alasan (Navon-Venezia et al., 1995). The contribution of protein components to the emulsifying potential of bioemulsifiers have also been reported in the literature. Sar and Rosenberg (1983) have also demonstrated that the protein content of bioemulsifier plays an important role in the emulsification activity.

Mannoproteins are glycoproteins extracted from the cell walls of many yeasts. These molecules are classified as structural and enzymatic mannoproteins depending on their chemical compositions and specific functions in living systems. Structural mannoproteins are the most abundant and are composed of a small protein portion linked to a greater carbohydrate portion (mannopyranosyl) while enzymatic mannoproteins have more protein moieties in their structures. These molecules are not only effective emulsifiers but have been associated with stimulation of host immunity by activating immune cells and proteins as well as triggering the production of antibodies (Casanova et al., 1992; Oliveira et al., 2009). A mannoprotein bioemulsifier from Kluyveromyces marxianus has been reported to form a 3-month old stable emulsion in corn oil (Lukondeh et al., 2003). Alcantara et al. (2014) reported a mannoprotein bioemulsifier from Saccharomyces cerevisiae 2031 consisting of $77 \%$ carbohydrate and $23 \%$ protein. A bioemulsifier with $53 \%$ protein, $42 \%$ polysaccharide and only $2 \%$ lipid has been reported from Acinetobacter sp. by Jagtap et al. (2010). These mannoprotein emulsifiers were capable of forming stable emulsions with different hydrocarbons, organic solvents and waste oils, suggesting their applications as cleaning agents.

Chemical components such as uronic acid have also been associated with the emulsifying capability of bioemulsifiers. Halomonas eurihalina produces an exopolysaacharide (EPS) that 
TABLE 1 | Physicochemical properties of biosurfactants and bioemulsifiers.

\begin{tabular}{|c|c|c|c|c|c|}
\hline Biosurfactant & Class & Microbial origin & Physicochemical properties & Physiological roles & References \\
\hline \multirow[t]{3}{*}{$\begin{array}{l}\text { Low molecular } \\
\text { weight } \\
\text { Glycolipid }\end{array}$} & Rhamnolipids & $\begin{array}{l}\text { Pseudomonas aeruginosa } \\
\text { DS10-129 }\end{array}$ & $\begin{array}{l}\text { One or two rhamnose sugars linked } \\
\text { to 3-hydroxydecanoic acid. } \\
\text { ST- } 28 \mathrm{mN} / \mathrm{m} \\
\text { El24- 53-73\% }\end{array}$ & $\begin{array}{l}\text { Bioremediation } \\
\text { technology }\end{array}$ & Rahman et al., 2002 \\
\hline & Sophorolipids & $\begin{array}{l}\text { Candida bombicola } \\
\text { Candida tropicalis }\end{array}$ & $\begin{array}{l}\text { Disaccharide sophoroses (2-O- } \beta \text {-D- } \\
\text { glucopyranosyl-D-glucopyranose) } \\
\text { linked to fatty acids. } \\
\text { ST- } 32.1-34.2 \mathrm{mN} / \mathrm{m}\end{array}$ & $\begin{array}{l}\text {-Detergent additive for } \\
\text { enhanced performance } \\
\text { and stain removal } \\
\text {-Hard surface cleaning, } \\
\text { Antibacterial activity. }\end{array}$ & $\begin{array}{l}\text { Develter and } \\
\text { Lauryssen, 2010; } \\
\text { Joshi-Navare et al., } \\
2013\end{array}$ \\
\hline & Trehaloselipid & $\begin{array}{l}\text { Rhodococcus } \\
\text { wratislaviensis BN38 } \\
\text { Norcardia farcinica BN26 }\end{array}$ & $\begin{array}{l}\text { Non-reducing disaccharide with two } \\
\text { glucose units linked in an } \\
\alpha, \alpha-1,1-\text { glycosidic linkage } \\
\text { ST-24.4 mN/m } \\
\text { El- } 23-70 \%\end{array}$ & $\begin{array}{l}\text { Bioremediation of } \\
\text { polluted sites, } \\
\text { Antitumor activity }\end{array}$ & $\begin{array}{l}\text { Tuleva et al., 2008; } \\
\text { Christova et al., } 2014\end{array}$ \\
\hline \multirow[t]{3}{*}{ Lipopeptides } & Surfactin & $\begin{array}{l}\text { Bacillus subtilis } K 1 \\
\text { Bacillus siamensis }\end{array}$ & $\begin{array}{l}\text { Heptacyclic depipeptides consisting } \\
\text { of two acidic amino acids, four } \\
\text { hydrophobic amino acids and } \\
\mathrm{C}_{13-17} \beta \text {-hydroxyfatty acids } \\
\text { ST- } 22-27.9 \mathrm{mN} / \mathrm{m}\end{array}$ & $\begin{array}{l}\text {-Enhanced oil recovery } \\
\text {-Antibacterial } \\
\text {-Antiviral } \\
\text {-Antimycoplasma } \\
\text {-Antitumoral } \\
\text {-Anticoagulant } \\
\text {-Enzyme inhibition }\end{array}$ & $\begin{array}{l}\text { Ongena and Jacques, } \\
2007 ; \\
\text { Varadavenkatesan and } \\
\text { Ramachandra, 2013; } \\
\text { Pathak and Keharia, } \\
2014\end{array}$ \\
\hline & Iturin & $\begin{array}{l}\text { Bacillus subtilis K1 } \\
\text { Bacillus amylofaciens }\end{array}$ & $\begin{array}{l}\text { Cycloheptapeptide with seven amino } \\
\text { acids and C13-16 } \beta \text {-amino fatty acids } \\
\text { ST-30-37 mN/m } \\
\text { El- } 32-66 \%\end{array}$ & $\begin{array}{l}\text {-Antifungal } \\
\text {-Biopesticides }\end{array}$ & $\begin{array}{l}\text { Arrebola et al., 2010; } \\
\text { Pathak and Keharia, } \\
2014\end{array}$ \\
\hline & Fengycin & Bacillus subtilis & $\begin{array}{l}\text { Cyclic deca-depsipeptides with } \\
\text { C14-21 } \beta \text {-hydroxyfatty acid and } 10 \\
\text { amino acids }\end{array}$ & $\begin{array}{l}\text {-Strong fungitoxic } \\
\text { agent against } \\
\text { filamentous fungi, } \\
\text { Immunomodulating } \\
\text { activities }\end{array}$ & $\begin{array}{l}\text { Arrebola et al., 2010; } \\
\text { Pathak and Keharia, } \\
2014\end{array}$ \\
\hline \multirow[t]{5}{*}{$\begin{array}{l}\text { High molecular } \\
\text { weight- } \\
\text { Bioemulsifiers }\end{array}$} & RAG-1 Emulsan & $\begin{array}{l}\text { Acinetobacter sp. ATCC } \\
31012 \text { (RAG-1) }\end{array}$ & $\begin{array}{l}\text { Lipopolysaccharides. Lipid moiety } \\
\text { (unsaturated fatty acid of C10-18) } \\
\text { Polysaccharide moiety } \\
\text { (D-galactosamine, } \\
\text { D-galactosaminuronic acid, } \\
\text { di-amino-6-deoxy-D-glucose) }\end{array}$ & $\begin{array}{l}\text {-Increase surface area } \\
\text { and bioavailiability of } \\
\text { poorly-soluble } \\
\text { substrates } \\
\text {-Binding to toxic heavy } \\
\text { metals }\end{array}$ & $\begin{array}{l}\text { Choi et al., 1996; Ron } \\
\text { and Rosenberg, } 2001\end{array}$ \\
\hline & BD4 Emulsan & $\begin{array}{l}\text { Acinetobacter } \\
\text { calcoaceticus BD4 } 13\end{array}$ & $\begin{array}{l}\text { Protein-polysaccharide complex. } \\
\text { Polysaccharide moiety (repeating } \\
\text { heptasaccharides of L-rhamnose, } \\
\text { D-glucouronic acid, D-mannose) }\end{array}$ & $\begin{array}{l}\text { Stabilizes oil-in-water } \\
\text { emulsions }\end{array}$ & $\begin{array}{l}\text { Kaplan and Roseberg, } \\
\text { 1985; Kaplan et al., } \\
1987\end{array}$ \\
\hline & Alasan & $\begin{array}{l}\text { Acientobacter } \\
\text { radioresistens KA53 }\end{array}$ & $\begin{array}{l}\text { Alanine-containing polysaccharide } \\
\text { and proteins }\end{array}$ & $\begin{array}{l}\text { Emulsification and } \\
\text { solubilization activity }\end{array}$ & $\begin{array}{l}\text { Navon-Venezia et al., } \\
\text { 1995; Walzer et al., } \\
2006\end{array}$ \\
\hline & Mannoproteins & $\begin{array}{l}\text { Saccharomyces } \\
\text { cerevisiae } \\
\text { Kluyveromyces marxianus }\end{array}$ & Polysaacharide and proteins & $\begin{array}{l}\text { Formation of stable } \\
\text { emulsion with } \\
\text { hydrophobic substrates } \\
\text { Stimulation of immune } \\
\text { system }\end{array}$ & $\begin{array}{l}\text { Casanova et al., 1992; } \\
\text { Lukondeh et al., } 2003\end{array}$ \\
\hline & Uronic acid bioemulsifiers & $\begin{array}{l}\text { Halomonas eurihalina } \\
\text { Klebsiella sp. }\end{array}$ & $\begin{array}{l}\text { Polysaccharides-proteins-uronic } \\
\text { acids }\end{array}$ & $\begin{array}{l}\text { Emulsification and } \\
\text { detoxification of } \\
\text { hydrocarbons }\end{array}$ & $\begin{array}{l}\text { Martínez-Checa et al., } \\
\text { 2002; Jain et al., } 2013\end{array}$ \\
\hline
\end{tabular}

can efficiently emulsify hydrocarbons. This EPS is rich in uronic acids containing less carbohydrate and protein components. The uronic acid has been associated with the ability of EPS to emulsify and detoxify hydrocarbons (Martínez-Checa et al., 2002). Jain et al. (2013) also reported on a bioemulsifier with a molecular weight of $2716 \mathrm{kDa}$, consisting of mainly total sugars, uronic 
acids and proteins produced by Klebsiella sp. On a general note bioemulsifiers have been associated with a number of potential applications including: remediation of oil polluted water and soil; enhanced oil recovery and clean-up of oil contaminated vessels and machineries; heavy metal removal (Monteiro et al., 2010; Zheng et al., 2012; Panjiar et al., 2014); formation of stable emulsions in food and cosmetics industries (Campos et al., 2014); and therapeutic activities (antibacterial, antifungal, pesticidal and herbicidal agents) (Ahmed and Hassan, 2013). The physico-chemical properties of bioemulsifiers and biosurfactants are presented in Table $\mathbf{1}$.

At this point, it is important to note that the ability to reduce surface and interfacial tension stands as the distinctive contrast between biosurfactant and bioemulsifiers. These molecules can both form stable emulsions but it is still unclear why bioemulsifiers do not show significant changes in surface/interfacial tension between different phases (liquid-air, liquid-liquid, liquid-solid). This outstanding contrast between biosurfactants and bioemulsifiers is especially important for accurate screening and identification procedures from microbial culture broths.

Screening for detection of biological surfactants in culture media has often been based on the measurement of surface and interfacial tension. Other methods include drop collapse, oil displacement, haemolysis tests and use of the emulsification index $\mathrm{E}_{24}$ (Cooper and Goldenberg, 1987), emulsification activity (Rahman et al., 2002, 2010; Satpute et al., 2008), and bacterial adhesion to hydrocarbon assay (BATH) also known as cell surface hydrophobicity (Rosenberg et al., 1980). According to Satpute et al. (2008), these methods are insufficient for the identification and differentiation of bioemulsifiers from biosurfactants. This is due to the fact that bioemulsifiers are best known for emulsification of liquids without significant changes in surface/interfacial tension of their growth medium or between different phases. In addition, experimental reports have shown that surface tension measurements and emulsification index/activity screening methods do not correlate. These methods have often resulted in elimination of bioemulsifiers since they do not exhibit significant changes in surface/interfacial tension and may give negative results during screening tests (Ellaiah et al., 2002). Emulsification index $\mathrm{E}_{24}$ and emulsification activity are screening tests for measuring the emulsification capacity of any surface active molecule with different hydrocarbons (Jagtap et al., 2010). BATH is an indirect screening method to detect cell-bound emulsifying agents produced by microorganisms. Cell-bound surface active agents are important in hydrocarbon assimilation during biodegradation and bioremediation of polluted environment. When microorganisms show low surface hydrophobicity it is an indication that emulsifying agents have been released extracellularly into the production media.

Using the emulsification index $\mathrm{E}_{24}$ test, Viramontes-Ramos et al. (2010) identified six isolates that could efficiently emulsify different hydrocarbons (more than 50\% against diesel, decane, kerosene and motor oil) without showing a significant reduction in surface tension of their culture broths. The emulsifying potential of surface active compounds from different yeasts showing no reduction in surface tension, has been evaluated using the emulsification index test (Amaral et al., 2006; Monteiro et al., 2010). Toledo et al. (2008) reported the growth and production of exopolymers by three bacteria, Bacillus subtilis 28, Alcaligenes faecalis 212, and Enterobacter sp. 214 on glucose media amended with different hydrocarbons. These biopolymers exhibited high emulsifying activity but without reduction in surface tension of their culture media. Candida tropicalis grown on n-hexadecane produced an extracellular emulsifier with surface tension of 49.5 $\mathrm{mN} / \mathrm{m}$ but was capable of emulsifying various hydrocarbons including aromatic hydrocarbons (Singh and Desai, 1989). Souza et al. (2012) identified a potent bioemulsifier produced by Yarrowia lipolytica which exhibited high emulsification values with hydrocarbons, with no reduction in surface tension.

\section{Concluding Remarks}

A number of literature reports have regarded all microbial surfactants as biosurfactants even when bioemulsifiers have been identified. These two types of surfactants are closely related especially in their ability to form stable emulsions. However, screening methods for identification of microbial surfactants based on surface tension reduction are bound to eliminate producers of bioemulsifiers and retain producers of biosurfactants. Therefore, the opinion of authors in this review is that bioemulsifiers are not biosurfactants (they both emulsify, but only biosurfactants have the surfactant effect of reducing surface tension) and current research toward identification should be based on a broad spectrum of tests and not only on surface tension measurements, which are often used as primary tests. In addition, there is minimal research on the discovery and characterization of new emulsifiers from microorganisms due to the lack of a clear picture of the distinguishing features between biosurfactants and bioemulsifiers. Biosurfactants and bioemulsifiers are both unique microbial products showing advantageous features and may become future substitutes for chemically produced ones. We have noted that bioemulsifiers have often been erroneously eliminated or mis-identified in the past but, since these molecules have great potential for green technology, carefully designed screening methods will be an essential step toward the discovery of novel microbial emulsifiers.

\section{Acknowledgments}

PR wishes to thank Commonwealth Scholarship Commission (UK) for PhD studentship award (CU, award ref: NGCS-2012335). 


\section{References}

Ahmed, E. F., and Hassan, S. S. (2013). Antimicrobial activity of a bioemulsifier produced by Serratia marcescens S10. J. AL-Nahrain Univ. 16, 147-155. Available online at: http://www.iasj.net/iasj?func=fulltext\&aId $=67186$

Alcantara, V. A., Pajares, I. G., Simbahan, J. F., and Edding, S. N. (2014). Downstream recovery and purification of a bioemulsifier from Sacchromyces cerevisiae 2031. Phil. Agric. Sci. 96, 349-359.

Amaral, P. F. F., da Silva, J. M., Lehocky, M., Barros-Timmons, A. M. V., Coelho, M. A. Z., Marrucho, I. M., et al. (2006). Production and characterization of a bioemulsifier from Yarrowia lipolytica. Proc. Biochem. 41, 1894-1898. doi: 10.1016/j.procbio.2006.03.029

Arrebola, E., Jacobs, R., and Korsten, L. (2010). Iturin A is the principal inhibitor in the biocontrol activity of Bacillus amyloliquefaciens PPCB004 against postharvest fungal pathogens. J. Appl. Microbiol. 108, 386-395. doi: 10.1111/j.13652672.2009.04438.x

Calvo, C., Manzanera, M., Silva-Castro, G. A., UAD, I., and GonzalezLopez, J. (2009). Application of bioemulsifiers in soil oil bioremediation processes. Future prospects. Sci. Total Environ. 407, 3634-3640. doi: 10.1016/j.scitotenv.2008.07.008

Campos, J. M., Stamford, T. L. M., and Sarubbo, L. A. (2014). Production of a bioemulsifier with potential application in the food industry. Appl. Biochem. Biotech. 172, 3234-3252. doi: 10.1007/s12010-014-0761-1

Casanova, M., Ribot, J. L. L., Martínez, J. P., and Sentandreu, R. (1992). Characterization of cell wall proteins from yeast and mycelial cells of Candida albicans by labelling with biotin: comparison with other techniques. Infect Immun. 60, 4898-4906.

Choi, J. W., Choi, H. G., and Lee, W. H. (1996). Effects of ethanol and phosphate on emulsan production by Acinetobacter calcoaceticus RAG-1. J. Biotechnol. 45, 217-225. doi: 10.1016/0168-1656(95)00175-1

Christova, N., Lang, S., Wray, V., Kaloyanov, K., Konstantinova, S., and Stoineva, I. (2014). Production, structural elucidation and in-vitro antitumor activity of trehalose lipid biosurfactant from Norcadia farcinia strain. J. Microbiol. Biotechnol. 24. doi: 10.4014/jmb.1406.06025. [Epub ahead of print].

Cooper, D. G., and Goldenberg, B. G. (1987). Surface-active agents from two Bacillus species. Appl. Environ. Microbiol. 53, 224-229.

Develter, D. W. G., and Lauryssen, L. M. L. (2010). Properties and industrial applications of sophorolipids. Eur. J. Lipid Sci. Tech. 112, 628-638. doi: 10.1002/ejlt.200900153

Ellaiah, P., Prabhakar, T., Sreekanth, M., Taleb, A. T., Raju, P. B., and Saisha, V. (2002). Production of glycolipids containing biosurfactants by Pseudomonas species. Ind. J. Exp. Biol. 40, 1083-1086.

Jain, R. M., Mody, K., Joshi, N., Mishra, A., and Jha, B. (2013). Production and structural characterization of biosurfactant produced by an alkaliphilic bacterium, Klebsiella sp: evaluation of different carbon sources. Coll. Surf. B Biointerf. 108, 199-204. doi: 10.1016/j.colsurfb.2013.03.002

Jagtap, S., Yavankar, S., Pardesi, K., and Chopade, B. (2010). Production of bioemulsifier by Acinetobacter sp. from healthy human skin of tribal population. Ind. J. Expt. Biol. 48, 70-76.

Joshi-Navare, K., Khanvilkar, P., and Prabhune, A. (2013). Jatropha oil derived sophorolipids: production and characterization as laundry detergent additive. Biochem. Res. Int. 3, 133-143. doi: 10.1155/2013/169797

Kaplan, N., and Roseberg, E. (1985). Exopolysaccharide distribution of and bioemulsifier production by Acinetobacter calcoaceticus BD4 and BD13. Appl. Environ. Microbiol. 44, 1335-1341.

Kaplan, N., Zosim, Z., and Rosenberg, E. (1987). Reconstitution of emulsifying activity of Acinetobacter calcoaceticus BD5 emulsan by using pure polysaccharide and proteins. Appl. Environ. Microbiol. 53, 440-446.

Lukondeh, T., Ashbolt, N., and Rogers, P. (2003). Evaluation of Kluyveromyces marxianus F11 510700 grown on a lactose-based medium as a source of natural bioemulsifier. J. Ind. Microbiol. Biotechnol. 30, 715-730. doi: 10.1007/s10295003-0105-6

Martínez-Checa, F., Toledo, F. L., Vilchez, R., Quesada, E., and Calvo, C. (2002). Yield production, chemical composition and functional properties of emulsifier H28 synthesized by Halomonas eurihalina strain H-28 in media containing various hydrocarbons. Appl. Microbial. Biotechnol 58, 358-363. doi: 10.1007/s00253-001-0903-6
Monteiro, A. S., Bonfim, M. R., Domingues, V. S., Correa, A. Jr., Siqueira, E. P., Zani, C. L., et al. (2010). Identification and characterization of bioemulsifier-producing yeasts isolated from effluents of a diary industry. Bioresour. Technol. 101, 5186-5193. doi: 10.1016/j.biortech.2010.02.041

Navon-Venezia, S., Zosim, Z., Gottlieb, A., Legman, R., Carmeli, S., Ron, E. Z., et al. (1995). Alasan, a new bioemulsifier from Acinetobacter radioresistens. Bio-emulsifier. Crit. Rev. Microbiol. 4, 39-66.

Oliveira, M. C., Figueiredo-Lima, D. F., Faria Filho, D. E., Marques, R. H., and Moraes, V. M. B. (2009). Effect of mannanoligosaccharides and/or enzymes on antibody titers against infectious bursal and Newcastle disease viruses. Arq. Bras. Med. Vet. 61, 6-11. doi: 10.1590/S0102-09352009000100002

Ongena, M., and Jacques, P. (2007). Bacillus lipopeptides: versatile weapons for plant disease biocontrol. Trends. Microbiol. 16, 115-125. doi: 10.1016/j.tim.2007.12.009

Panjiar, N., Sachan, S. G., and Sachan, A. (2014). Screening of bioemulsifierproducing microorganisms isolated from oil-contaminated sites. Ann. Microbiol. doi: 10.1007/s13213-014-0915-y

Pathak, K. V., and Keharia, H. (2014). Application of extracellular lipopeptide biosurfactant produced by endophytic Bacillus subtilis $\mathrm{K} 1$ isolated from aerial roots of banyan (Ficus benghalensis) in microbially enhanced oil recovery (MEOR). 3 Biotech. 4, 41-48. doi: 10.1007/s13205-013-0119-3

Perfumo, A., Smyth, T. J. P., Marchant, R., and Banat, I. M. (2009). "Production and roles of biosurfactant and bioemulsifiers in accessing hydrophobic substrates," in Microbiology of Hydrocarbons, Oils, Lipids and Derived Compounds, ed Kenneth N. Timmis (Berlin; Heidelberg: Springer-Verlag), 1502-1512.

Rahman, K. S. M., Thahira-Rahman, J., McClean, S., Marchant, R., and Banat, I. M. (2002). Rhamnolipid biosurfactants production by strains of Pseudomonas aeruginosa using low cost materials. Biotechnol. Prog. 18, 1277-1281. doi: 10.1021/bp020071x

Rahman, P. K. S. M., Pasirayi, G., Auger, V., and Ali, Z. (2010). production of rhamnolipid biosurfactant by Pseudomonas aeruginosa DS10-129 in a microfluidic bioreactor. Biotech. Appl. Biochem. 55, 45-52. doi: 10.1042/BA20090277

Ron, E. Z., and Rosenberg, E. (2001). Natural roles of biosurfactants. Environ. Microbiol. 3, 229-236. doi: 10.1046/j.1462-2920.2001.00190.x

Rosenberg, M., Gutnick, D. L., and Rosenberg, E. (1980). Adherence of bacteria to hydrocarbons: a simple method for measuring cell-surface hydrophobicity. FEMS Microbiol. Lett. 9, 29-33. doi: 10.1111/j.1574-6968.1980.tb05599.x

Sar, N., and Rosenberg, E. (1983). Emulsifier production by Acenetobacter cacoaaceticus strains. Curr. Microbiol. 9, 309-314.

Satpute, S. K., Banpurkar, A. G., Dhakephalkar, P. K., Banat, I. M., and Chopade, B. A. (2010). Methods of investigating biosurfactants and bioemulsifiers: a review. Crit. Rev. Biotechnol. 30, 127-144. doi: 10.3109/07388550903427280

Satpute, S. K., Bhawsar, B. D., Dhakephalkar, P. K., and Chopade, B. A. (2008). Assessment of different screening methods for selecting biosurfactant producing marine bacteria. Ind. J. Marine Sci. 37, 243-250. Available online at: http://nopr.niscair.res.in/bitstream/123456789/2045/1/IJMS\%2037 $\% 283 \% 29 \% 20243-250$.pdf

Sekhon-Randhawa, K. K. (2014). "Biosurfactants produced by genetically manipulated microorganisms: challenges and opportunities," in Biosurfactants, eds N Kosaric and F. V. Sukan (Boca Raton, FL: CRC Press), 49-67.

Singh, M., and Desai, J. D. (1989). Hydrocarbon emulsification by Candida tropicalis and Debaryomyces polymorphus. Indian J. Exp. Biol. 27, 224-226.

Smyth, T. J. P., Perfumo, A., Marchant, R., and Banat, I. M. (2010a). "Isolation and analysis of low molecular weight microbial glycolipids," in Handbook of Hydrocarbon and Lipid Microbiology, ed K. N. Timmis (Berlin; Heidelberg: Springer-Verlag), 3706-3723. doi: 10.1007/978-3-540-77587-4_291

Smyth, T. J. P., Perfumo, A., Marchant, R., and Banat, I. M. (2010b). "Isolation and Analysis of Lipopeptide and high molecular weight biosurfactant," in Handbook of Hydrocarbon and Lipid Microbiology, ed K. N. Timmis (Berlin; Heidelberg: Springer-Verlag), 3687-3704. doi: 10.1007/978-3-540-775874_290

Souza, F. A. S. D., Salgueiro, A. A., and Albuquerque, C. D. C. (2012). Production of bioemulsifier by Yarrowia lipolytica in sea water using diesel oil as the carbon source. Braz. J. Chem. Eng. 29, 61-67. doi: 10.1590/S0104-66322012000 100007

Toledo, F. L., Gonzalez-Lopez, J., and Calvo, C. (2008). Production of bioemulsifier by Bacillus subtilis, Alcaligenes faecalis and Enterobacter species in 
liquid culture. Bioresour. Technol. 99, 8470-8475. doi: 10.1016/j.biortech.2007. 08.055

Tuleva, B., Christova, N., Cohen, R., Stoev, G., and Stoineva, I. (2008). Production and structural elucidation of trehalose tetraesters biosurfactant from novel alkanothrophic Rhodococcus wratislaviensis strain. J. Appl. Microbiol. 104, 1703-1710. doi: 10.1111/j.1365-2672.2007.03680.x

Varadavenkatesan, M. T., and Ramachandra, M. V. (2013). Production of a lipopeptide biosurfactant by a novel Bacillus sp. and its applicability to enhanced oil recovery. ISRN Microbiol. 3, 1-8. doi: 10.1155/2013/621519

Viramontes-Ramos, S., Portillo-Ruiz, M. C., Ballinas-Casarrubias, M. L., TorresMunoz, J. V., Rivera-Chavira, B. E., and Nevarez-Moorillon, G. V. (2010). Selection of biosurfactant/bioemulsifier-producing bacteria from hydrocarboncontaminated soil. Braz. J. Microbiol. 41, 668-675. doi: 10.1590/S151783822010000300017

Walzer, G., Rosenberg, E., and Ron, E. Z. (2006). The Acinetobacter outer membrane protein A (OmpA) is a secreted emulsifier. Environ. Microbiol. 8, 1026-1032. doi: 10.1111/j.1462-2920.2006.00994.x
Willumsen, P. A., and Karlson, U. (1997). Screening of bacteria, isolated from PAH-contaminated soil, for production of biosurfactants and bioemulsifiers. Biodegradation 7, 415-423. doi: 10.1007/BF00056425

Zheng, C., Li, Z., Su, J., Zhang, R., Liu, C., and Zhao, M. (2012). Characterization and emulsifying property of a novel bioemulsifier by Aeribacillus pallidus YM-1. J. Appl. Microbiol. 113, 44-51. doi: 10.1111/j.1365-2672.2012.05313.x

Conflict of Interest Statement: The authors declare that the research was conducted in the absence of any commercial or financial relationships that could be construed as a potential conflict of interest.

Copyright (C) 2015 Uzoigwe, Burgess, Ennis and Rahman. This is an open-access article distributed under the terms of the Creative Commons Attribution License (CC $B Y)$. The use, distribution or reproduction in other forums is permitted, provided the original author(s) or licensor are credited and that the original publication in this journal is cited, in accordance with accepted academic practice. No use, distribution or reproduction is permitted which does not comply with these terms. 